\title{
PERANCANGAN SISTEM PENDUKUNG KEPUTUSAN DENGAN MENERAPKAN METODE PROFILE MATCHING SEBAGAI ALTERNATIF PENENTUAN DOSEN FAVORIT PILIHAN MAHASISWA
}

\author{
${ }^{[1]}$ Himawan Eka Sanjaya, ${ }^{[2]}$ Abdi Pandu Kusuma, ${ }^{[3]}$ Filda Febrinita \\ ${ }^{[1]}$ Universitas Islam Balitar, ${ }^{[2]}$ Universitas Islam Balitar, ${ }^{[3]}$ Universitas Islam Balitar
}

\begin{abstract}
Abstrak : Tenaga pendidik atau kependidikan pada perguruan tinggi yang khusus diangkat dengan tugas utama mengajar adalah Dosen (PP. No.60 /1999). Dosen merupakan salah satu faktor penentu dalam keberhasilan proses pendidikan. Menurut UU No.14 Pasal 14 /2005, dosen wajib memiliki kualifikasi akademik, kompetensi, sertifikat pendidik, sehat jasmani dan rohani, dan memenuhi kualifikasi lain yang dipersyaratkan satuan pendidikan tinggi tempat bertugas, serta memiliki kemampuan untuk mewujudkan tujuan pendidikan nasional. Dengan demikian, dosen diharapkan mampu melaksanakan kinerjanya dengan baik dan tepat. Kinerja dosen pada suatu universitas dapat diketahui salah satunya melalui penilaian angket dosen favorit oleh mahasiswa.Penilaian angket ini dapat dikemas dalam suatu aplikasi Sistem Pendukung Keputusan sebab SPK memiliki kemampuan untuk memecahkan masalah dengan kondisi semi terstruktur dan tak terstruktur.Pada penelitian ini, SPK dirancang dengan menggunakan metode Profile Matching. Pada aplikasi SPK ini, penilaian dosen favorit didasarkan pada tiga aspek utama sebagai acuan dalam pengambilan keputusan. Aspek yang digunakan, yaitu aspek interaksi, perilaku, dan pembelajaran. Dari aplikasi SPK yang telah dirancang, dilakukan pengujian degan menggunakan metode BlackBox. Hasil pengujian black box menunjukkan bahwa aplikasi dapat berjalan 96,29\% sesuai dengan yang diharapkan. Sedangkan untuk uji kelayakan pada ahli pemograman diperoleh nilai 3,08 (Cukup) dan untuk uji kelayakan penguji praktisi diperoleh nilai 3,7 (Baik). Perhitungan perankingan dari penguji praktisi, didapatkan dosen favorit pilihannya adalah M. Nasichin Al Muiz dengan nilai ranking 5,652 .
\end{abstract}

Kata Kunci : Penilaian angket, Profile Matching, Dosen Favorit.

\section{Pendahuluan}

Tenaga pendidik atau kependidikan pada perguruan tinggi yang khusus diangkat dengan tugas utama mengajar adalah Dosen ${ }^{[1]}$. Dosen ikut berperan dalam menentukan keberhasilan proses pendidikan, karena dosen yang memberikan ilmu 
pada mahasiswa. Dosen merupakan salah satu bagian penting yang ada pada sebuah universitas. Kehadiran, pengalaman, serta cara mengajar dosen merupakan faktor yang mempengaruhi prestasi mahasiswa. Oleh karena itu, dosen wajib memiliki kualifikasi akademik, kompetensi, sertifikat pendidik, sehat jasmani dan rohani, dan memenuhi kualifikasi lain yang dipersyaratkan satuan pendidikan tinggi tempat bertugas, serta memiliki kemampuan untuk mewujudkan tujuan pendidikan nasional ${ }^{[2]}$. Dengan demikian, dosen diharapkan mampu melaksanakan kinerjanya dengan baik dan tepat.

Kinerja dosen pada suatu universitas dapat diketahui salah satunya melalui penilaian angket dosen favorit oleh mahasiswa. Penilaian angket ini dapat dikemas dalam suatu aplikasi Sistem Pendukung Keputusan (SPK). sebab SPK memiliki kemampuan untuk memecahkan masalah dengan kondisi semi terstruktur dan tak terstruktur, dimana tak seorangpun tahu secara pasti bagaimana keputusan seharusnya dibuat $^{[3]}$. Selain itu, SPK jugadilengkapidengankemampuan berpikir besertapengembangankeahliandalamlingkuptertentu. Pada penelitian ini,SPK diprioritaskan sebagai acuan penulis untuk menjadi salah satu bagian dari sistem informasi berbasis komputer yang akan diimplementasikan kedalam bentuk website.

Untuk merancang SPK, dibutuhkan suatu metode yang tepat dan sesuai dengan tujuan yang ingin dicapai. Salah satu metode yang dapat digunakan untuk merancang SPK adalah metode profile matching.Profile Matching (PM) merupakan metodeyangmengasumsikan bahwa terdapat tingkat variabel prediktor yang ideal yang harus dipenuhi oleh subyek yang diteliti, bukannya tingkat minimal yang harus dipenuhi atau dilewati ${ }^{[4]}$. Proses Profile Matching secara garis besar merupakan proses membandingkan antara nilai data aktual dari suatu profil yang akan dinilai dengan nilai profil yang diharapkan sehingga dapat diketahui perbedaan kompetensinya (nilai gap). Semakin kecil gap yang dihasilkan maka bobot nilainya semakin besar. Ini berarti, dosen yang nantinya memiliki nilai gap terkecil adalah dosen yang memiliki peluang besar untuk direkomendasikan sebagai dosen favorit.

Dari uraian diatas, maka peneliti merancang Sistem Pendukung Keputusan penilaian angket untuk menentukan dosen favorit dengan menggunakan metode Profile Matching. Melalui perancangan sistem ini, diharapkan dapat membantu pihak pengelola kampus dalam menentukan dosen favorit yang telah dipilih oleh mahasiswa, khususnya pada Program Studi Teknik Informatika. Selain itu, hasil dari sistem ini juga diharapkan dapat menjadi bahan pertimbangan Kaprodi maupun pengelola dari Program Studi Teknik Informatika untuk melakukan evaluasi dan refleksi dari kinerja dosen. 


\section{Metode Penelitian}

\section{A. Waktu dan Tempat Penelitian}

Penelitian dilakukan di Universitas Islam Balitar, Fakultas Teknologi Informasi, Program Studi Teknik Informatika pada bulan Agustus - September 2017. Peneliti memilih UNISBA sebagai tempat penelitian sebab di UNISBA, khususnya di FTI Prodi Teknik Informatika, untuk proses penilaian kinerja dosen oleh mahasiswa masih menggunakan form di kertas. Oleh karena itu, peneliti akan mengubah sistem penilaian tersebut kedalam sebuah program berbasis web.

\section{B. Metode Pengumpulan Data}

Adapun metode pengumpulan data yang digunakan pada penelitian tugas akhir ini dilakukan dengan melakukan berbagai tahapan, diantaranya sebagai berikut.

\section{Sumber data primer}

Sumber data primer diperoleh melalui teknik pengumpulan data secara langsung (peneliti melakukan tanya jawab dengan narasumber). Berikut merupakan teknik untuk memperoleh data langsung yang dilakukan peneliti.

\section{a. Observasi}

Observasi dilakukan dengan mengamati form penilaian dosen untuk mengetahui permasalahan yang terjadi pada saat pengisian form penilaian dosen (lama).

\section{b. Wawancara}

Wawancara dilakukan pada Bapak Abdi Pandu Kusuma S.kom, M.T selaku Kaprodi Teknik Informatika, untuk memperoleh data mengenai proses penilaian dosen oleh mahasiswa yang selama ini telah dilakukan Prodi TI.

\section{Sumber data sekunder}

Sumber data sekunder dilakukan melalui teknik pengumpulan data secara tidak langsung (peneliti tidak langsung melakukan tanya jawab dengan narasumber). Berikut merupakan teknik untuk memperoleh data tidak langsung yang dilakukan peneliti.

\section{a. Studi dokumentasi}

Studi dokumentasi dilakukan dengan melihat dan menganalisis dokumen - dokumen yang dibuat oleh Dikti sebagai acuan sumber referensi utama dalam pembuatan aplikasi. Pengambilan data penilaian kinerja dosen di kelas tertuang pada halaman 88 
- 89, Bahan Pelatihan Sistem Penjaminan Mutu Internal Perguruan Tinggi tahun 2016 yang disusun oleh Kementrian Riset, Teknologi, dan Pendidikan Tinggi Direktorat Jenderal Pembelajaran dan Kemahasiswaan Direktorat Penjaminan Mutu. Selain itu, peneliti juga memperoleh Data Dosen aktif tahun ajaran 2017/2018 dan Data Mahasiswa semester 8 Program Studi Teknik Informatika Fakultas Teknologi Informasi dari Sekretaris Kaprodi Teknik Informatika.

\section{b. Kuisioner (Angket)}

Kuisioner dibuat berdasarkan pada data wawancara maupun studi dokumentasi yang dilakukan. Kuisioner ditulis dengan membuat daftar pertanyaan yang ditujukan kepada responden untuk melengkapi data yang dibutuhkan.

\section{Perancangan Sistem}

Adapun tahapan dalam perancangan aplikasi yangdibuat oleh peneliti diantaranya adalah pembuatan Data flow diagram (DFD), Flowchart, dan Entity relationship diagram (ERD).

\section{Data flow diagram (DFD)}

Data flow diagram digunakan untuk memodelkan sistem secara logis. Seperti halnya bagan alir dokumen, diagram alir data pun dapat digunakan baik pada tahap analisis maupun tahap desain. Namun, kecenderungan diagram ini lebih cocok digunakan untuk tahap desain karena dengan diagram tersebut batasan ruang lingkup sistem terlihat sangat jelas sehingga pekerjaan pengembangan sistem yang dilakukan dapat lebih fokus. Berikut merupakan DFD yang dibuat oleh peneliti untuk pembuatan aplikasi.

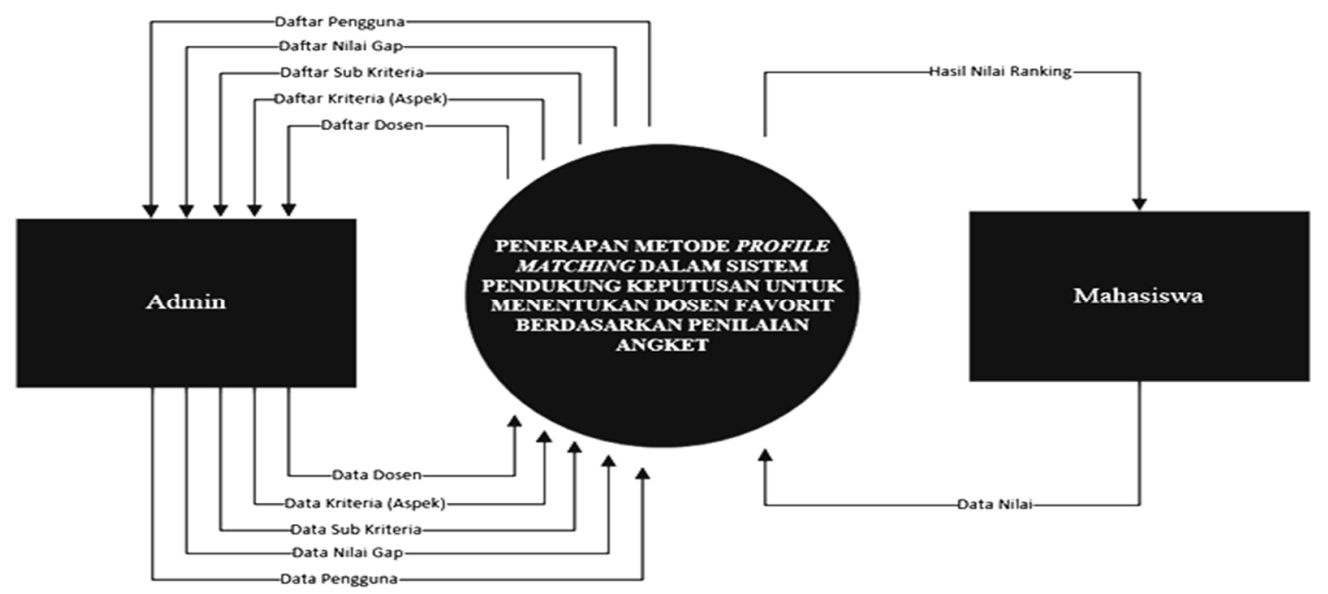

Gambar 1 DFD level 0 
Berdasarkan Gambar 1, dapat diperoleh informasi sebagai berikut.

a. Admin memberikan inputan berupa data dosen, lalu admin menerima outputan berupa daftar dosen.

b. Admin memberikan inputan berupa data kriteria (aspek), lalu admin menerima outputan berupa daftar kriteria (aspek).

c. Admin memberikan inputan berupa data sub kriteria, lalu admin menerima outputan berupa daftar sub kriteria.

d. Admin memberikan inputan berupa data nilai gap, lalu admin menerima outputan berupa daftar nilai gap.

e. Admin memberikan inputan berupa data pengguna, lalu admin menerima outputan berupa daftar pengguna.

f. Mahasiswa memberikan inputan berupa data nilai, lalu mahasiswa menerima outputan berupa hasil nilai ranking.

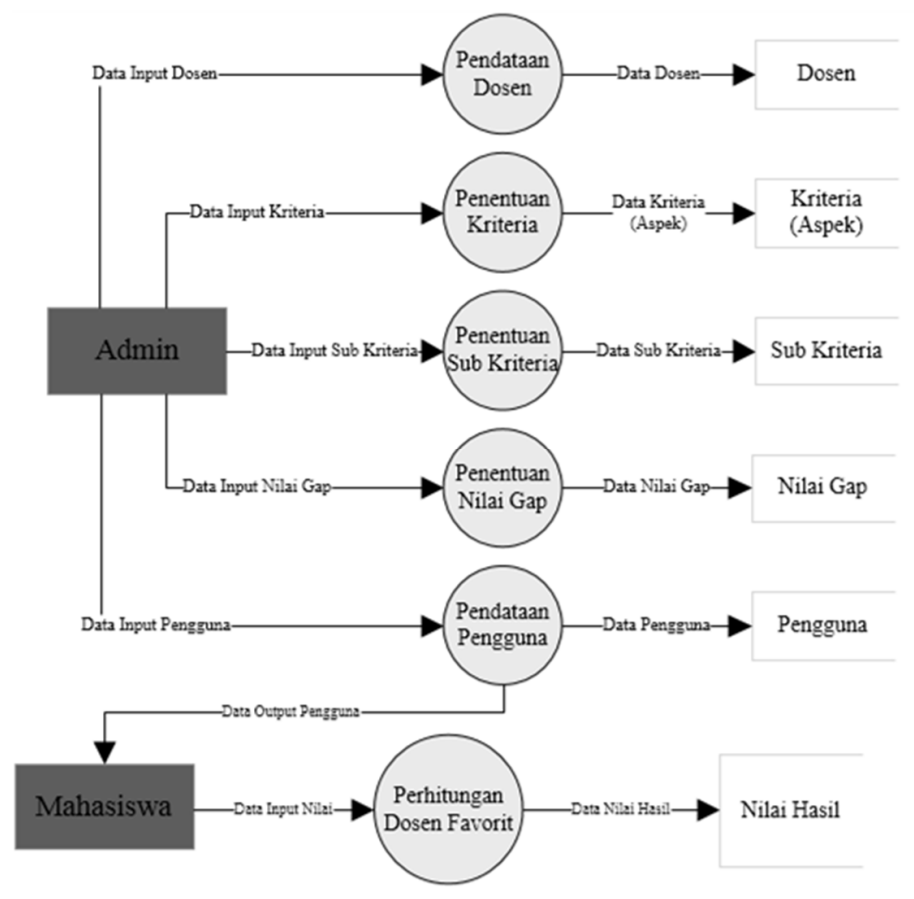

Gambar 2 DFD level 1 
Berdasarkan Gambar 2 di atas, dapat diperoleh informasi sebagai berikut.

a. Admin memberikan inputan berupa data dosen, lalu data dosen yang ada akan diolah pada database dosen, nantinya database tersebut akan menampilkan daftar dosen dari data yang di inputkan.

b. Admin memberikan inputan berupa data kriteria (aspek), lalu data kriteria (aspek) yang ada akan diolah pada database kriteria (aspek), nantinya database tersebut akan menampilkan daftar kriteria (aspek) dari data yang di inputkan.

c. Admin memberikan inputan berupa data sub kriteria, lalu data sub kriteria yang ada akan diolah pada database sub kriteria, nantinya database tersebut akan menampilkan daftar sub kriteria dari data yang di inputkan.

d. Admin memberikan inputan berupa data nilai gap, lalu data nilai gap yang ada akan diolah pada database nilai gap, nantinya database tersebut menampilkan daftar nilai gap dari data yang di inputkan.

e. Admin memberikan inputan berupa data pengguna, lalu data pengguna yang ada akan diolah pada database pengguna, nantinya database tersebut akan menampilkan daftar pengguna dari data yang di inputkan.

f. Data pengguna yang terdatar nantinya akan diturunkan pada Mahasiswa, sebagai username.

g. Mahasiswa memberikan inputan berupa data nilai, lalu data nilai yang ada akan diolah pada database nilai hasil, nantinya database tersebut akan menampilkan daftar perankingan dari data nilai hasil.

\section{Flowchart}

Flowchart merupakan alat yang digunakan untuk melakukan perencanaan proses, analisis proses dan mendokumentasikan proses sebagai standar pedoman produksi. Berikut merupakan Flowchart yang dibuat oleh peneliti untuk pembuatan aplikasi. 


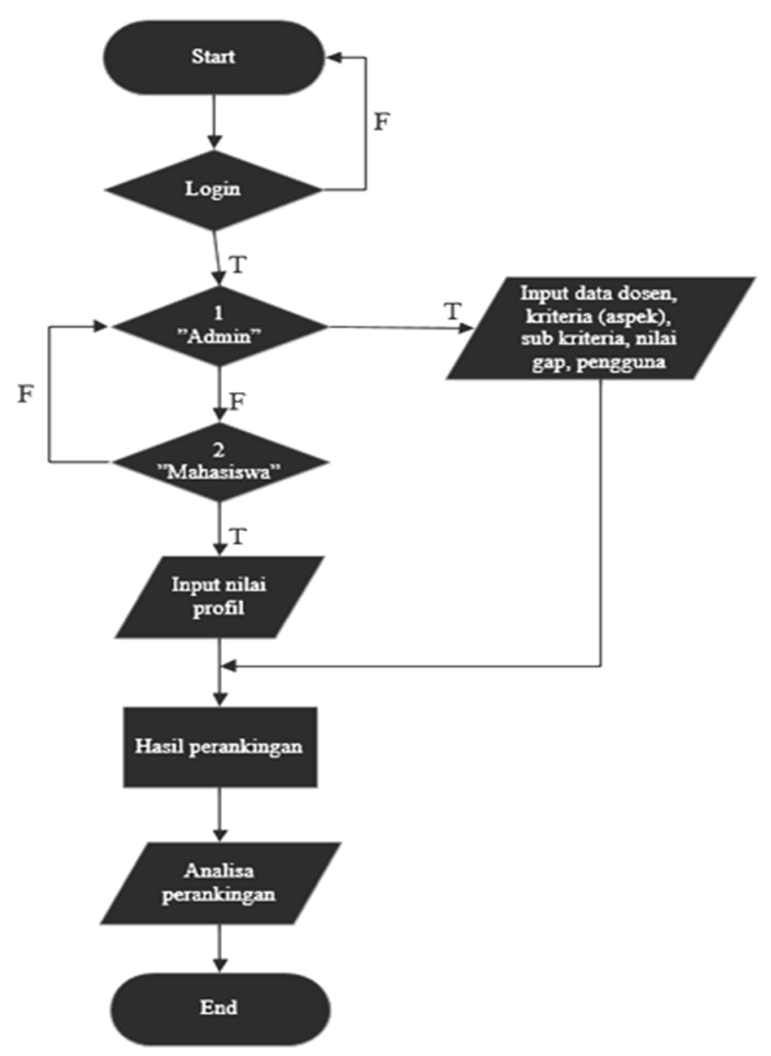

Gambar 3 Flowchart sistem

Berdasarkan Gambar 3 dapat dilihat bahwa proses dimulai dari start > lalu direkomendasikan untuk login sebagai syarat utama. Apabila salah, maka akan kembali lagi dari start dan apabila berhasil maka terdapat 2 pilihan, yaitu login sebagai "admin" atau "mahasiswa". Selanjutnya, apabila login sebagai admin, maka hak aksesnya adalah input data dosen, kriteria (aspek), sub kriteria, nilai gap, dan pengguna. Sedangkan apabila login sebagai mahasiswa, maka hak aksesnya adalah input data nilai profil. Nantinya, admin maupun mahasiswa akan mendapat hasil berupa hasil perankingan serta outputan berupa analisa perankingan.

\section{Entity relationship diagram (ERD)}

Entity relationship diagrammerupakan suatu model untuk menjelaskan hubungan antar data dalam basis data berdasarkan objek-objek dasar data yang mempunyai hubungan antar relasi. Entitas adalah suatu objek yang dapat di definisikan dalam lingkungan pemakai. Relasi menunjukkan adanya hubungan di antara sejumlah entitas yang berbeda. Atribut berfungsi mendeskripsikan karakter 
entitas (atribut yang berfungsi sebagai key di beri garis bawah). Garis sebagai penghubung antara relasi dan entitas atau relasi dan entitas dengan atribut. Berikut merupakan DFD yang dibuat peneliti untuk pembuatan aplikasi.

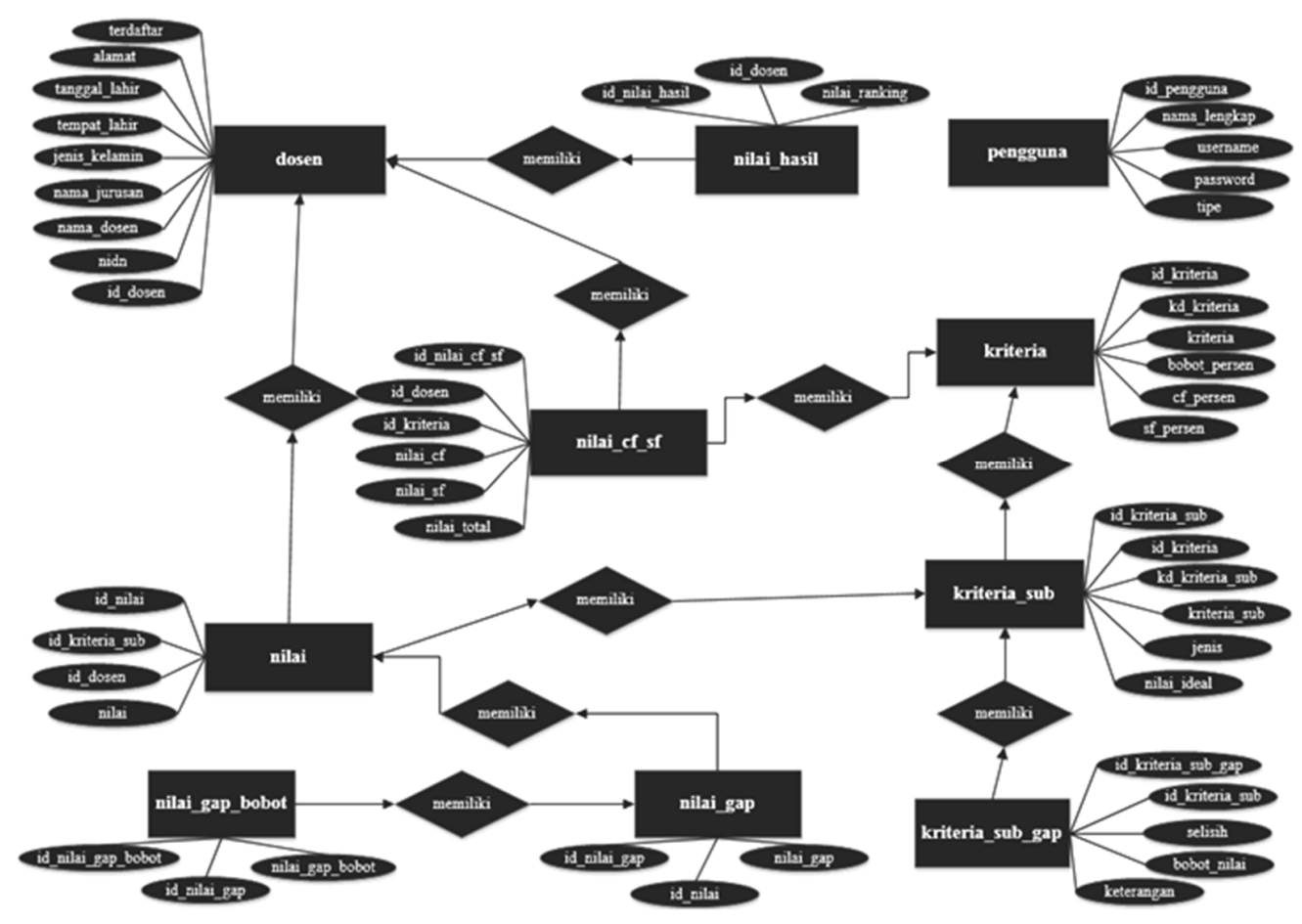

Gambar 4 Entity relationship diagram (ERD)

Adapun keterangan dari Gambar 4 adalah sebagai berikut.

a. Entitas dosen memiliki 9 atribut, relasi dengan entitas nilai, entitas nilai_hasil, dan entitas nilai_cf_sf.

b. Entitas kriteria memiliki 6 atribut, relasi dengan entitas kriteria_sub dan entitas nilai_cf_sf.

c. Entitas kriteria_sub memiliki 6 atribut, relasi dengan entitas kriteria.

d. Entitas kriteria_sub_gap memiliki 5 atribut, relasi dengan entitas kriteria_sub.

e. Entitas nilai memiliki 4 atribut, relasi dengan entitas kriteria_sub.

f. Entitas nilai_cf_sf memiliki 6 atribut, relasi dengan entitas dosen dan entitas kriteria. 
g. Entitas nilai_gap memiliki 3 atribut, relasi dengan entitas nilai.

h. Entitas nilai_gap_bobot memiliki 3 atribut, relasi dengan entitas nilai_gap.

i. Entitas nilai_hasil memiliki 3 atribut, relasi dengan entitas dosen.

j. Entitas pengguna memiliki 5 atribut.

\section{Hasil Dan Pembahasan}

\section{A. Hasil}

Adapun hasil yang diperoleh dari aplikasi yang telah dibuat,dibagi menjadi beberapa tampilan, antara lain sebagai berikut.

\section{Tampilan halaman data nilai profil}

Pada halaman ini mahasiswa dapat mengisi nilai profil dari dosen.Selanjutnya, data nilai profil yang telah di inputkan akan diproses untuk menentukan dosen favorit.

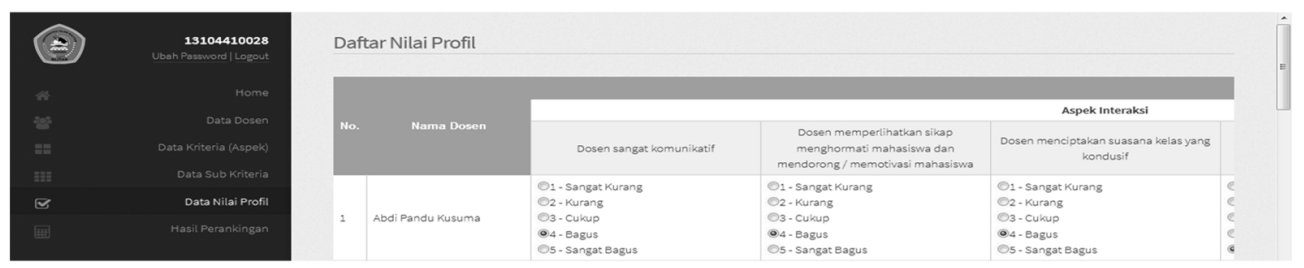

Gambar 5 Tampilan halaman data nilai profil

\section{Tampilan halaman hasil perhitungan (selisih gap)}

Pada halaman ini mahasiswa / admin dapat melihat perhitungan nilai profil, nilai ideal, dan nilai gap (selisih).
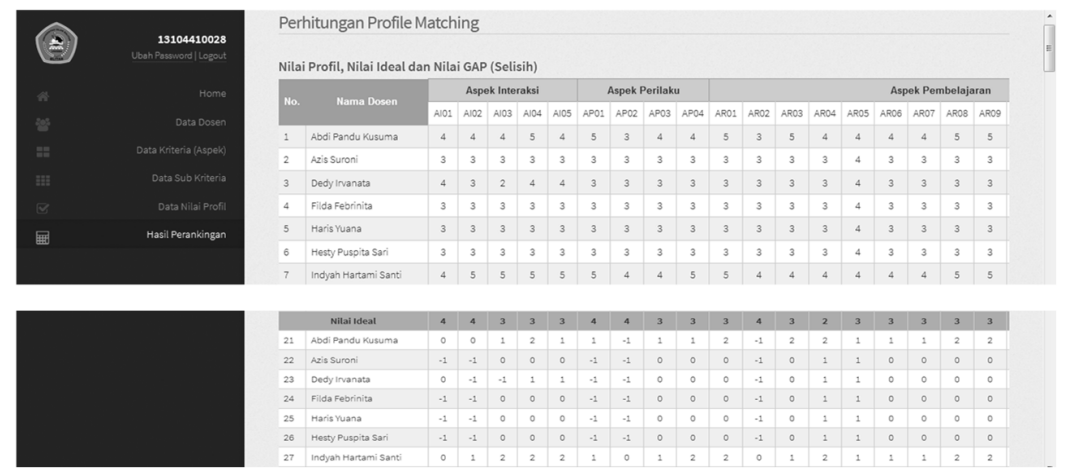

Gambar 6 Tampilan halaman hasil perhitungan (selisih gap) 


\section{Tampilan halaman hasil perhitungan (pembobotan nilai gap)}

Pada halaman ini mahasiswa / admin dapat melihat perhitungan nilai bobot gap dari setiap aspek.
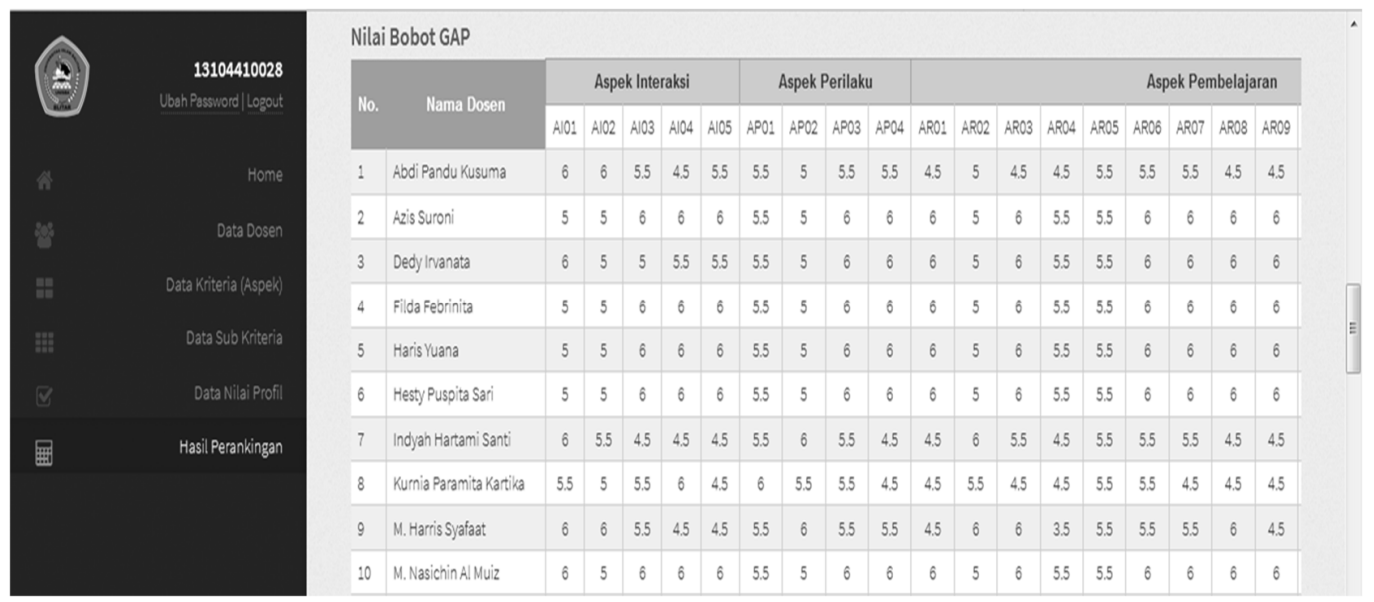

Gambar 7 Tampilan halaman hasil perhitungan (pembobotan nilai gap)

\section{Tampilan halaman hasil perhitungan (cf, sf, dan nilai total)}

Pada halaman ini mahasiswa / admin dapat melihat perhitungan cf, sf, dan nilai total dari setiap aspek.
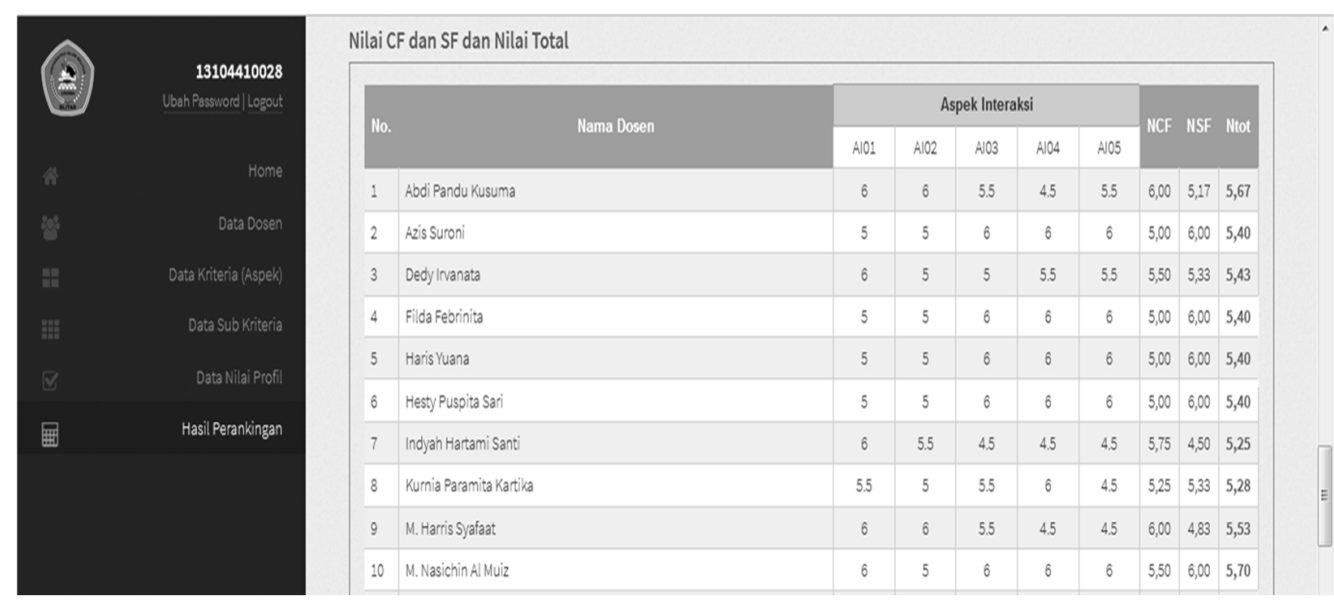

Gambar 8 Tampilan halaman hasil perhitungan (nilai cf, sf, dan nilai total) 


\section{Tampilan halaman hasil perhitungan (ranking)}

Pada halaman ini mahasiswa / admin dapat melihat hasil perhitungan nilai ranking dosen favorit.

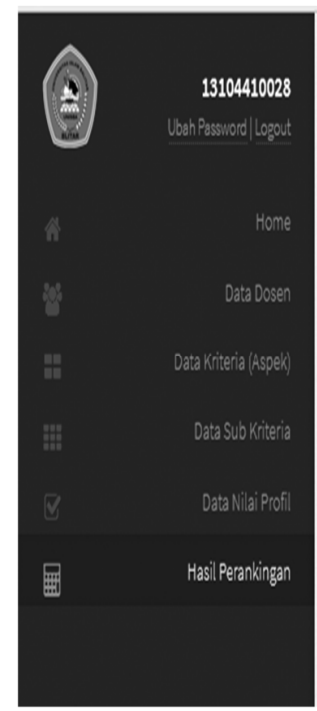

\begin{tabular}{|c|c|c|c|c|c|}
\hline \multicolumn{6}{|c|}{ Nilai Ranking } \\
\hline No & Nama Dosen & Nitot $_{\text {Aspek interaksi }}$ & Ntot $_{\text {Aspek Perilaku }}$ & Ntot $_{\text {Aspek Pembeljajaran }}$ & Nilai Ranking \\
\hline : & M. Nasichin AI Múz & 5,70 & 5,55 & 5,69 & 5,652 \\
\hline 2 & Dedy Inanata & 5,43 & 5,55 & 5,69 & 5,585 \\
\hline 3 & Azis Suroni & 5,40 & 5,55 & 5,69 & 5,577 \\
\hline 4 & Filda Feorinita & 5,40 & 5,55 & 5,69 & 5,577 \\
\hline 5 & Haris Yvana & 5,40 & 5,55 & 5,69 & 5,577 \\
\hline 6 & Hessy Pusoita Sari & 5,40 & 5,55 & 5,69 & 5,577 \\
\hline 7 & Rahadhian Adhiwardhana & 5,40 & 5,55 & 5,69 & 5,577 \\
\hline 8 & Yusniarsi Pimasari & 5,40 & 5,55 & 5,69 & 5,577 \\
\hline 9 & Sabitul Kirom & 5,40 & 5,55 & 5,65 & 5,557 \\
\hline 10 & Wahyu Dwi Pusoita & 5,40 & 5,45 & 5,59 & 5,500 \\
\hline
\end{tabular}

Gambar 9 Tampilan halaman hasil perhitungan (ranking)

\section{B. Pembahasan}

Berikut akan dipaparkan perhitungan manual dari data yang diambil melalui penguji praktisi (mahasiswa) dengan menggunakan urutan rumus - rumus pada metode profile matching.

\section{Profile Matching}

Pada metode profile matching, diasumsikan bahwa terdapat tingkat variabel prediktor yang ideal yang harus dipenuhi oleh subyek yang diteliti, bukannya tingkat minimal yang harus dipenuhi atau dilewati ${ }^{[4]}$.

Proses profile matchingsecaragarisbesarmerupakan proses membandingkan antara nilai data aktual dari suatu profile yang akan dinilai dengan nilai profil yang diharapkan sehingga dapat diketahui perbedaan kompetensinya (disebut juga gap). Semakin kecilgap yang dihasilkan, maka bobot nilainya semakin besar. Ini berarti, dosen yang memiliki nilai gap terkecil, memiliki peluang paling besar untuk direkomendasikansebagai dosen favorit pilihan mahasiswa. 
Adapun beberapa tahapan dan perumusan perhitungan dengan metodeprofile matching sebagai berikut.

\section{a. Perhitungan Selisih Gap}

Pada tahap ini, akan dihitung nilai selisih dari nilai profil yang telah di inputkan pada tiap - tiap sub kriteria dengan nilai ideal. Berikut merupakan rumus yang digunakan untuk menghitung selisih $\operatorname{gap}^{[4]}$ :

$$
\text { Gap = Profil dari data yang di tes - profil minimal }
$$

\section{b. Perhitungan Pembobotan Nilai Gap}

Setelah diperoleh nilai gap dari data angket, setiap nilai profil yang di inputkan akan diberikan bobot nilai sesuai dengan ketentuan pada Tabel 1. Pada tahap ini, akan ditentukan bobot nilai masing-masing aspek dengan menggunakan bobot nilai yang telah ditentukan bagi masing-masing aspek itu sendiri. Dalam penentuan peringkat pada setiap aspek diberikan bobot nilai sesuai dengan Tabel berikut ${ }^{[4]}$ :

TABEL 1

BOBOT NILAI GAP

\begin{tabular}{cccc}
\hline \hline No & Selisih Gap & Bobot Nilai & Keterangan \\
\hline 1 & 0 & 6 & Kompetensi sesuai dengan yang dibutuhkan \\
\hline 2 & 1 & 5.5 & Kompetensi individu kelebihan1 tingkat / level \\
\hline 3 & -1 & 5 & Kompetensi individu kurang 1Tingkat/level \\
\hline 4 & 2 & 4.5 & Kompetensi individu Kelebihan 2Tingkat/level \\
\hline 5 & -2 & 4 & Kompetensi individu kurang 2Tingkat/level \\
\hline 6 & 3 & 3.5 & Kompetensi individu kelebihan 3Tingkat/level \\
\hline 7 & -3 & 3 & Kompetensi individu kurang 3Tingkat/level \\
\hline 8 & 4 & 2.5 & Kompetensi individu kelebihan 4Tingkat/level \\
\hline 9 & -4 & 2 & Kompetensi individu kurang 4Tingkat/level \\
\hline \hline
\end{tabular}

\section{c. Perhitungan dan pengelompokan core dan secondary factor}

Setelah menentukan bobot nilai gap untuk ketiga aspek yang dibutuhkan, tiap sub aspek dikelompokan lagi menjadi 2 kelompok yaitu core factor dan secondary factor. 


\section{1) Core factor}

Core faktor merupakanaspek(kompetensi)yangpaling menonjol atau paling dibutuhkan oleh suatu jabatan yang diperkirakan dapat menghasilkan kinerja optimal. Untuk menghitung core factor digunakan rumus ${ }^{[4]}$ :

$$
N C F=\sum \frac{N C}{I C}
$$

\section{Keterangan :}

$\mathrm{NCF}=$ Nilai rata-rata core factor

$\mathrm{NC}=$ Jumlah total nilai core factor

IC = Jumlah item core factor

2) Secondary factor

Secondary factor merupakan aspek pendukung lainyangadapadacore factor. Untuk menghitung secondary factor digunakan rumus ${ }^{[4]}$ :

$$
N S F=\sum \frac{N S}{I S}
$$

\section{Keterangan :}

$\mathrm{NSF}=$ Nilai rata-ratasecondary factor

NS = Jumlah total nilai secondary factor

IS = Jumlah item secondary factor

\section{d. Perhitungan Nilai Total}

Berdasarkan perhitungan core factor dan secondary factor dari tiap-tiap aspek, selanjutnya dihitung nilai total dari tiap-tiap aspek yang diperkirakan berpengaruh pada kinerja tiap-tiap profile. Untuk menghitung nila total dari masingmasing aspek, digunakan rumus ${ }^{[4]}$ :

$$
\boldsymbol{N}=(\mathrm{X} \%) \boldsymbol{N C F}+(\mathrm{X} \%) \mathbf{N S F}
$$

\section{Keterangan :}

$$
\begin{array}{ll}
\mathrm{N} & =\text { Nilai Total } \\
\mathrm{NCF} & =\text { Nilai rata-rata Core Factor } \\
\mathrm{NSF} & =\text { Nilai rata-rata Secondary Factor }
\end{array}
$$




\section{e. Perhitungan ranking}

Hasilakhir dari proses profile matching adalah ranking dari kandidat yang diajukan untuk mengisi suatu jabatan / posisi tertentu. Penentuan ranking mengacu pada hasil perhitungan yang ditujukan pada rumus dibawah ini ${ }^{[4]}$ :

Ranking $=(\%) \mathbf{N C F}+(\%) \mathbf{N S F}$

\section{Keterangan :}

Rangking $=$ Nilai akhir

$\mathrm{NCF}=$ Nilai Core Factor

$\mathrm{NSF} \quad=$ Nilai Secondary Factor

\section{Implementasi}

Berikut akan dipaparkan implementasi perhitungan manual yang diperoleh dari data yang diambil melalui penguji praktisi (mahasiswa), mulai dari perhitungan selisih gap, perhitungan pembobotan nilai gap, perhitungan dan pengelompokan core dan secondary factor, perhitungan nilai total, dan perhitungan nilai ranking. Berikut merupakan implementasi dari rumus - rumus yang digunakan.

\section{a. Perhitungan selisih gap}

Pada tahap ini, akan dihitung nilai selisih dari nilai profil yang telah di inputkan pada tiap - tiap sub kriteria dengan nilai ideal. Berikut adalah contoh perhitungan selisih gap berdasarkan rumus (1).

a) $\operatorname{Gap}[1][1]=4-4=0$

b) $\operatorname{Gap}[1][1]=3-4=-1$

c) $\operatorname{Gap}[1][1]=4-4=0$

d) $\operatorname{Gap}[1][1]=3-4=-1$

\section{b. Pembobotan nilai gap}

Setelah diperoleh nilai gap pada tiap data dosen, setiap nilai profil yang di inputkan akan diberikan bobot nilai sesuai dengan ketentuan pada Tabel 1.

\section{c. Perhitungan dan pengelompokan core dan secondary factor}

Setelah menentukan bobot nilai gap untuk ketiga kriteria (aspek) yang dibutuhkan, kemudian tiap sub kriteria dikelompokan lagi menjadi 2 kelompok yaitu core factor dan secondary factor. 


\section{1) Aspek Interaksi}

Pada aspek interaksi terdapat 2 core factor dan 3 secondary factor, berikut adalah perhitungannya berdasarkan rumus (2) dan (3) :

a) Core factor
i. $\quad N C F[$ Data 1$]=\sum \frac{6+6}{2}=6$
ii. $N C F[$ Data2 $]=\sum \frac{5+5}{2}=5$

b) Secondary factor
i. $N S F[$ Data 1$]=\sum \frac{5,5+4,5+5,5}{3}=5,16$
ii. $N S F[$ Data2 $]=\sum \frac{6+6+6}{3}=6$

\section{2) Aspek Perilaku}

Pada aspek perilaku terdapat 2 core factor dan 2 secondary factor, berikut adalah perhitungannya berdasarkan rumus (2) dan (3) :
a) Core factor
i. $N C F[$ Data1 $]=\sum \frac{5,5+5}{2}=5,25$
ii. $N C F[$ Data2 $]=\sum \frac{5,5+5}{2}=5,25$
b) Secondary factor
i. $N S F[$ Data 1$]=\sum \frac{5,5+5,5}{2}=5,5$
ii. $N S F[$ Data2 $]=\sum \frac{6+6}{2}=6$

\section{3) Aspek pembelajaran}

Pada aspek perilaku terdapat 5 core factor dan 9 secondary factor, berikut adalah perhitungannya berdasarkan rumus (2) dan (3) :
a) Core factor
i. $\quad N C F[$ Data 1$]=\sum \frac{4,5+5+5,5+5+5,5}{5}=5,2$
ii. $N C F[$ Data2 $]=\sum \frac{6+5+6+6+5}{5}=5,6$
b) Secondary factor
i. $N S F[$ Data1 $]=\sum \frac{4,5+4,5+5,5+4,5+4,5+6+4,5+4,5+4,5}{9}=4,77$
ii. $N S F[$ Data2 $]=\sum \frac{6+5,5+5,5+6+6+6+5,5+6+6}{9}=5,83$ 


\section{d. Perhitungan Nilai Total}

Dari hasil perhitungan setiap aspek yang ada, selanjutnya dilakukan perhitungan nilai total berdasarkan persentase dari nilai core factor dan secondary factor. Nilai yang ditetapkan adalah $60 \%$ untuk core factor serta $40 \%$ untuk secondary factor. Berikut adalah perhitungan nilai total pada setiap aspek berdasarkan rumus (4).

1) Aspek interaksi
a) $\mathrm{N}[$ Data1 $]=(60 \%) 6+(40 \%) 5,16=3,6+2,06=5,66$
b) $\mathrm{N}[$ Data2] $=(60 \%) 5+(40 \%) 6=3+2,4=5,4$
c) $\mathrm{N}[$ Data3 $]=(60 \%) 5,5+(40 \%) 5,33=3,3+2,13=5,43$
d) $\mathrm{N}[$ Data4 $]=(60 \%) 5+(40 \%) 6=3+2,4=5,4$

2) Aspek perilaku
a) $\mathrm{N}[$ Data 1$]=(60 \%) 5,25+(40 \%) 5,5=3,15+2,2=5,35$
b) $\mathrm{N}[$ Data2 $]=(60 \%) 5,25+(40 \%) 6=3,15+2,4=5,55$
c) $\mathrm{N}[$ Data3 $]=(60 \%) 5,25+(40 \%) 6=3,15+2,4=5,55$
d) $\mathrm{N}[$ Data4 $]=(60 \%) 5,25+(40 \%) 6=3,15+2,4=5,55$

3) Aspek pembelajaran
a) $\mathrm{N}[$ Data 1$]=(60 \%) 5,2+(40 \%) 4,77=3,12+1,9=5,02$
b) $\mathrm{N}[$ Data2 $]=(60 \%) 5,6+(40 \%) 5,83=3,36+2,33=5,69$
c) $\mathrm{N}[$ Data3 $]=(60 \%) 5,6+(40 \%) 5,83=3,36+2,33=5,69$
d) $\mathrm{N}[$ Data4 $]=(60 \%) 5,6+(40 \%) 5,83=3,36+2,33=5,69$

\section{e. Perhitungan Ranking}

Penentuan hasil akhir dari semua perhitungan adalah dengan menggunakan persentase yang digunakan untuk tiap aspek. Aspek interaksi 25\%, aspek perilaku $30 \%$, dan aspek pembelajaran $45 \%$. Berikut adalah contoh perhitungannya berdasarkan rumus (5).
a) $\operatorname{Ranking}[$ Data1 $]=(25 \%) 5,66+(30 \%) 5,35+(45 \%) 5,02=1,415+$ $1,605+2,259=5,279$
b) $\operatorname{Ranking}[$ Data2 $]=(25 \%) 5,4+(30 \%) 5,55+(45 \%) 5,69=1,35+$ $1,665+2,56=5,575$
c) $\operatorname{Ranking}[$ Data3 $]=(25 \%) 5,43+(30 \%) 5,55+(45 \%) 5,69=1,357+$ $1,665+2,56=5,582$
d) $\operatorname{Ranking}[$ Data4 $]=(25 \%) 5,4+(30 \%) 5,55+(45 \%) 5,69=1,35+$ $1,665+2,56=5,575$


Kesimpulan yang didapat dari perhitungan ranking yang dilakukan secara manual menunjukkan bahwa dosen favorit pilihan adalah M. Nasichin Al Muiz. Data yang digunakan adalah data yang di inputkan oleh penguji praktisi. Selanjutnya, hasil pada setiap perhitungan manual dibandingkan dengan perhitungan melalui aplikasi yang dibuat. Dari perbandingan tersebut peneliti menemukan bahwa terdapat data yang berbeda 0,00 maupun $0,001-0,007$. Perbedaan ini itujukkan pada nama dosen Abdi Pandu Kusuma yang dikarenakan nilai total dari aspek interaksi berbeda 0,01 dan nilai total dari aspek pembelajaranberbeda 0,01 dari aplikasi. Adapun perankingan pada aplikasi ditunjukkan pada Gambar 10 berikut.

\begin{tabular}{|c|c|c|c|c|c|}
\hline \multicolumn{6}{|c|}{ Nilai Ranking } \\
\hline No. & Nama Dosen & Ntot $_{\text {Aspek Interaksi }}$ & Ntot $_{\text {Aspek Perilaku }}$ & Ntot $_{\text {Aspek Pembelajaran }}$ & Nilai Ranking \\
\hline 1 & M. Nasichin Al Muiz & 5,70 & 5,55 & 5,69 & 5,652 \\
\hline 2 & Dedy Invanata & 5,43 & 5,55 & 5,69 & 5,585 \\
\hline 3 & Azis Suroni & 5,40 & 5,55 & 5,69 & 5,577 \\
\hline 4 & Filda Febrinita & 5,40 & 5,55 & 5,69 & 5,577 \\
\hline 5 & Haris Yuana & 5,40 & 5,55 & 5,69 & 5,577 \\
\hline 6 & Hesty Puspita Sari & 5,40 & 5,55 & 5,69 & 5,577 \\
\hline 7 & Rahadhian Adhiwardhana & 5,40 & 5,55 & 5,69 & 5,577 \\
\hline 8 & Yusniarsi Primasari & 5,40 & 5,55 & 5,69 & 5,577 \\
\hline 9 & Sabitul Kirom & 5,40 & 5,55 & 5,65 & 5,557 \\
\hline 10 & Wahyu Dwi Puspita & 5,40 & 5,45 & 5,59 & 5,500 \\
\hline 11 & Udkhiati Mawaddah & 5,43 & 5,45 & 5,56 & 5,495 \\
\hline 12 & M. Harris Syafaet & 5,53 & 5,65 & 5,33 & 5,476 \\
\hline 13 & Riska Dhenabayu & 5,67 & 5,60 & 5,16 & 5,418 \\
\hline 14 & Indyah Hartami Santi & 5,25 & 5,45 & 5,22 & 5,296 \\
\hline 15 & Yufi Priyo Sutanto & 5,23 & 5,80 & 4,98 & 5,291 \\
\hline 16 & Abdi Pandu Kusuma & 5,67 & 5,35 & 5,03 & 5,286 \\
\hline 17 & Sri Lestanti & 4,93 & 5,65 & 5,15 & 5,246 \\
\hline 18 & Sunan Trioko & 5,52 & 5,30 & 5,04 & 5,236 \\
\hline 19 & Kurnia Paramita Kartika & 5,28 & 5,45 & 4,86 & 5,143 \\
\hline 20 & M. Taufik Chulkamdi & 3,40 & 3,40 & 4,22 & 3,770 \\
\hline
\end{tabular}

Gambar 10 Hasil perankingan

\section{KESIMPULAN DAN SARAN}

\section{A. Kesimpulan}

Adapun kesimpulan yang didapatkan dari hasil dan pembahasan dari proses perancangan aplikasi Sistem Pendukung Keputusan dengan menerapkan Metode Profile Matching Dalam Proses Penentuan Dosen Favorit adalah sebagai berikut.

a. Sistem Pendukung Keputusan dirancang untuk menentukan dosen favorit pilihan mahasiswa dengan hasil akhir perankingan yang bias dijadikan alternatif bagi 
kampus untuk membantu dan mempermudah dalam proses pengambilan keputusan pemilihan dosen favorit.

b. Aplikasi system pendukung keputusan ini dapat digunakan universitas, khususnya prodi Teknik Informatika, untuk mengetahui seberapa besar penilaian mahasiswa terhadap dosen dilihat dari perankingan yang dibuat.

c. Aplikasi ini dapat difungsikan sesuai perancangan dan desain yang telah dibuat, dimana kriteria (aspek) serta sub criteria yang digunakan mengacu pada ketentuan DIKTI.

d. Berdasarkan hasil pembahasan yang telah diuraikan diatas, maka dapat diambil kesimpulan bahwa perangkingan dengan mengunakan metode Profile Matching mampu menghasilkan keputusan yang proposional sesuai dengan kriteria (aspek), sub kriteria, bobot nilai ideal dan presentase kriteria (aspek) yang ditentukan.

\section{B. Saran}

Adapun saran yang ditujukan untuk peneliti selanjutnya apabila ingin mempelajari dan mengembangkan laporan maupun aplikasi yang telah dibuat adalah sebagai berikut.

a. Aplikasi yang dibuat oleh peneliti hanya menghasilkan perangkingan dosen favorite versi satu user (mahasiswa) yang tentunya bisa saja bersifat subyektif. Oleh karena itu, diharapkan pada penelitian selanjutnya bisa mengembangkan dan memperluas hasil perankingan dari semua user (lebih dari 1 mahasiswa) sehingga dapat diperoleh lagi perankingan keseluruhan yang diambil dari semua data yang di inputkan oleh semua mahasiswa.

b. Sebaiknya dilakukan penelitian lanjutan untuk mengembangkan aplikasi yang dibuat peniliti, sehingga dapat bermanfaat juga untuk Fakultas maupun Prodi lain.

c. Perlu adanya penelitian pengembangan yang dapat memunculkan aplikasi serupa tetapi menggunakan metode yang berbeda agar dapat dilakukan perbandingan keakuratan hasil aplikasi yang diperoleh.

\section{DAFTAR PUSTAKA}

Agustin, Y.H., dan Kurniawan, H. 2015. Sistem Pendukung Keputusan penilaian kinerja Dosen menggunakan metode Weighted Product (Studi kasus : STMIK Pontianak) . Seminar Nasional Informatika 2015.

Didik, W. 2016. Sistem Pendukung Keputusan evaluasi kinerja Mahasiswa dengan metode Profile Matching.Jurnal Informatika Vol.10, No.1, Jan 2016. 
Direktorat Jenderal Peraturan Perundang-undangan. 2014. PERATURAN PEMERINTAH NOMOR 60 TAHUN 1999. (online). (http://www.peraturan.go.id/pp/nomor-60-tahun-199911e44c4f41d36600993f313232303031.html). diakses 21Maret 2017.

Dore, L., dan Rajurkar, J. 2014. A Decision Support System for Predicting Student Performance. International Jurnal of Innovative Research of Computer and Communication Engineering, Vol.2, Issue 12 December 2012.

Kusrini. 2007. Konsep Aplikasi Sistem Pendukung Keputusan. Yogyakarta: Andi Offset.

Lembaran Negara Republik Indonesia. 2005. UNDANG-UNDANG REPUBLIK $\begin{array}{llll}\text { INDONESIA NOMOR } 14 & \text { TAHUN }\end{array}$ (http://www.sjdih.depkeu.go.id/fullText/2005/14TAHUN2005UU.htm). diakses 24 Maret 2017.

Safitri, M.Z., Adharani, Y., dan Susilowati,E. 2015. Penerapan Metode Simple Additive Weighting untuk penilaian kinerja dosen. Simposium Nasional Teknologi Terapan (SNTT)32015.

Sari, R.E., dan Saleh,A. 2014. Penilaian kinerja dosen dengan menggunakan metode AHP (Studi kasus : di STMIK Potensi Utama Medan). Seminar Nasional Informatika 2014.

Sumiati, dan Nuryadin, S. 2013. Sistem Pendukung Keputusan dalam menentukan penilaian kinerja Dosen dengan metode FuzzyDatabase Model Mamdani. Electrans, Vol.12, No.2, September 2013.

Turban, Efraim \& Aronson, Jay E. 2001. Decision Support Systems and Intelligent Systems. 6th edition. Prentice Hall: Upper Saddle River, NJ.

Zulita, L.N. 2013. Sistem Pendukung Keputusan menggunakan metode SAW untuk penilaian dosen berprestasi (Studi kasus di Universitas Dehasen Bengkulu). Jurnal Media Infotama, Vol.9, No.2, September 2013. 